\title{
SEX ANOMALIES IN PIGS
}

\author{
P. K. BASRUR AND H. KANAGAWA \\ Department of Biomedical Sciences, University of Guelph, \\ Guelph, Ontario, Canada
}

(Received 21st April 1970, revised 16th April 1971)

\begin{abstract}
Summary. Anatomical and histological examinations on three intersex pigs revealed that two of these carried bilateral ovotestes, welldeveloped uterine horns and female-like external genitalia, while the third had rudimentary male accessory sex glands and unequal uterine horns with an ovary attached to the right horn and a testis to the left. Chromosome analyses on blood and testicular tissue of the female-like intersexes showed exclusively XX cells whereas the intersex with male accessory sex glands exhibited a small proportion of $\mathrm{XY}$ cells in cultures of blood, testis and kidney, suggesting that the latter may be a whole body chimera. In contrast to these cattle freemartins, intersex pigs, including the two with ovotestes, carried apparently functional ovaries. The escape from virilization of the female gonads, despite their proximity to testes in intersex pigs, may be attributable to the biological nature of the testicular secretion which, in boars, is rich in sulphated oestrogens.
\end{abstract}

The male twins among cattle twins of unlike sex exhibit chimerism in blood and gonads whereas the virilized gonads of the female co-twins have never been shown to contain male cells (Ohno, Trujillo, Stenius, Christian \& Teplitz, 1962; Goodfellow, Strong \& Stewart, 1965; Teplitz, Moon \& Basrur, 1967). In such cattle freemartins, the gonads are generally inactive testes, although occasionally a freemartin maintaining the ovarian architecture may be noted (Basrur, Kosaka \& Kanagawa, 1970). In intersex pigs, the gonads are often represented by both testicular and ovarian tissues. This report concerns the cytogenetic make-up of three pigs which are recognized as intersexes on the basis of their external and internal genitalia. Two of these had enlarged clitoris, vagina, long bipartite uterine horns and bilateral ovotestes in which the ovarian part was located in the area occupied by the tunica albuginea. The third intersex (Intersex 3 ) had a penile clitoris, unequal uterine horns, a rudimentary prostate, a pair of seminal vesicle-like structures and gonads which consisted of an ovary on the right side and a testis with large epididymis on the left.

The testicular tissue in all cases consisted of narrow seminiferous tubules surrounded by prominent Leydig cells. The ovarian parts of the gonads in all of these pigs revealed follicles containing oocytes (Pl. 1, Figs. 1 and 2). Corpora lutea, similar to those of normal pigs, were noted in the intersexes including those with ovotestes (Pl. 1, Fig. 3), suggesting apparently normal ovarian activity in these animals.

Cultured cells from the testicular part of the gonads and blood samples from 
the two female-like intersexes revealed a normal female karyotype (Pl. 1, Fig. 4) although well-spread metaphase plates obtained from each preparation were few (nineteen from Intersex 1 and twenty from Intersex 2). In Intersex 3, eight out of twenty-eight cells in the blood culture and seven out of twentythree cells in the left gonad (testis) were of XY make-up while the balance in both tissues was of XX constitution. In two out of seventeen cells analysed from kidney cultures of Intersex 3, the sex complements were distinctly of the $\mathrm{XY}$ type (Pl. 1, Fig. 5).

True chimerism has been reported so far only in four intersex pigs, all of which had male gonads and rudimentary accessory sex glands (McFee, Knight \& Banner, 1966; Bruere, Fielden \& Hutchings, 1968; Vogt, 1968; Breeuwsma, 1970). The proportion of XY cells in blood cultures of these intersexes were low, except in one which showed $65 \% \mathrm{XY}$ cells (Breeuwsma, 1970). The ovary of the chimeric intersex of the present report differed from that of intersexes reported previously in that it was active in spite of the presence of a male gonad which appeared to be hormonally active. The presence of XY cells in kidney and in the testicular part of the gonad indicates that Intersex 3 may be a whole body chimera, probably resulting from double fertilization or fusion of $\mathrm{XX}$ and XY blastocysts. The occurrence of blastocyst fusion in pigs has been suggested at least in one study (McFeely, 1967) and it may well be a mechanism by which chimeric intersexes result in pigs.

It would appear that there are different grades, and possibly different causes, for intersexuality in different species. In goats, the 'polled' gene in homozygous state in a genetic female causes intersexuality which is characterized by the presence of male gonads in association with different female accessory reproductive organs (Basrur \& Coubrough, 1964; Hammerton, Dixon, Pollard, Grieves \& Short, 1969). In the equine, intersexes exhibit chimerism and a tendency for mitotic anomalies resulting in mosaicism (Basrur, Kanagawa \& Gilman, 1969). In goats, no ovarian tissue was ever observed, although a majority of the reported intersexes have been proved to be genetic females (Basrur \& Kanagawa, 1970). Pigs differ from goats and cattle in that some 'intersexes' are true hermaphrodites with meiotically inactive male gonads and functional ovaries. Pregnancy and normal farrowing have been reported in some intersex pigs with testis on one side and ovary on the other (Folger, 1932; Hulland, 1964; Cox, 1968) although the cytogenetic make-up of these intersexes has not been ascertained. The presence of corpora lutea in the ovotestes of our two intersexes indicates a functional state of ovaries located in the vicinity of hormonally active male gonads. The reason for the apparent lack of testicular

\section{EXPLANATION OF PLATE 1}

Fig. 1. The cortical region of the ovary (left ovotestis) in Intersex 2, showing primary follicles. $\times 410$.

FIG. 2. A growing follicle showing an ovum with large nucleus and prominent nucleolus, surrounded by follicular cells in the right ovotestis of Intersex $1 . \times 410$.

Fig. 3. Luteal cells of one of the corpora lutea in the right ovotestis of Intersex $1 . \times 410$. FIG. 4. A metaphase plate and photokaryotype of Intersex 1. Note the normal female pig complement including a pair of $\mathrm{X}$ chromosomes. $\times 2150$.

Fig. 5. A metaphase plate and photokaryotype of a cell from the kidney culture on Intersex 3, exhibiting the male sex chromosome complement. $\times 2150$. 

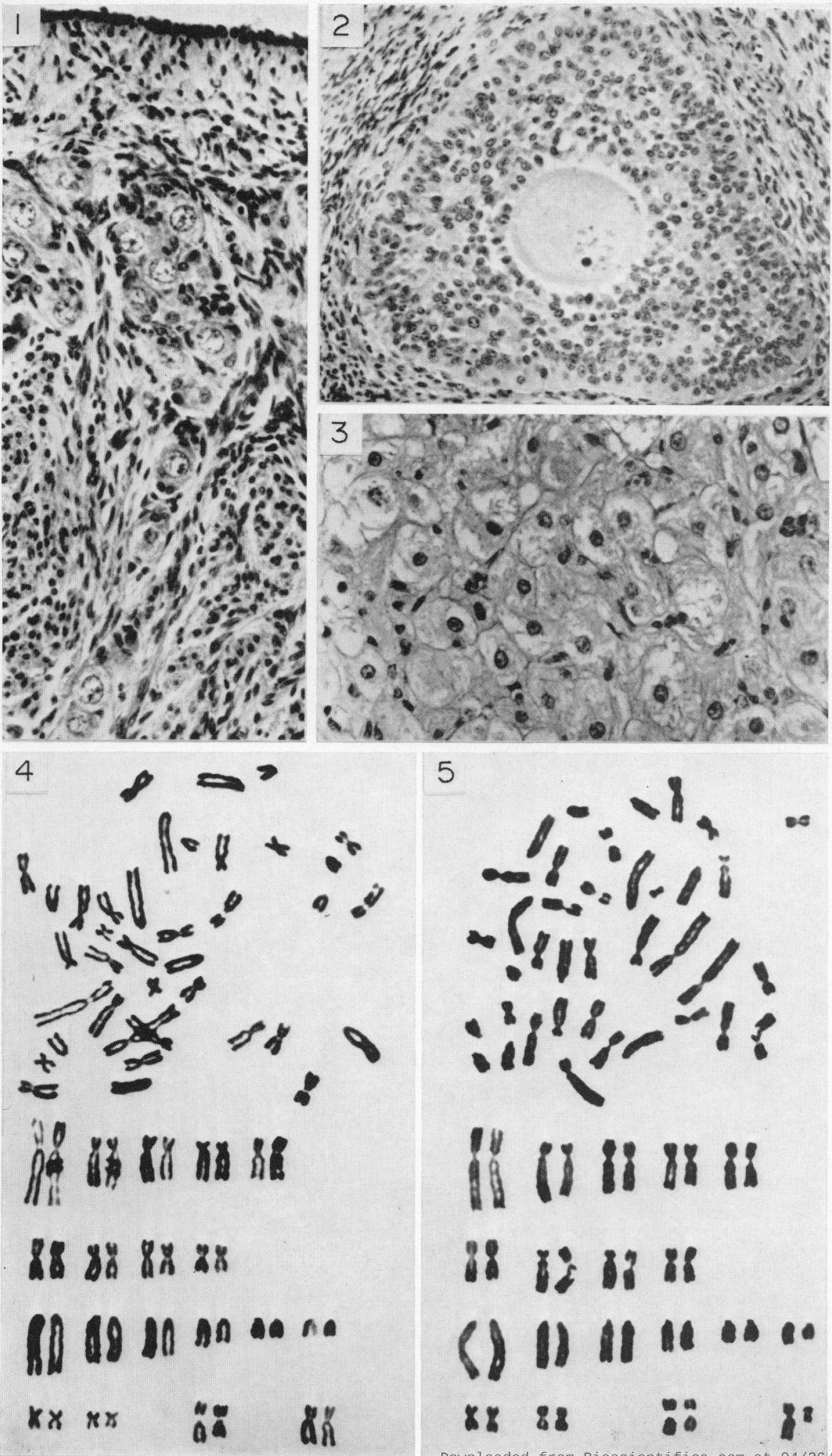
influence on the function of ovaries in hermaphrodite pigs is not known. In this regard, the observation of Breeuwsma (1970) is worthy of note. Breeuwsma noted trace amounts of testosterone in intersex pigs ranging in age from 27 days to 8 months while two 8-month-old intersexes and two older intersexes (one 9 months old and the other 13 months old) showed no detectable amount of testosterone. The most significant observation in this study (Breeuwsma, 1970) was that the normal male also exhibited no testosterone suggesting that the intersex gonads do not differ from normal boar gonads, at least during the early postnatal stages. Using oestradiol as substrate, Breeuwsma (1970) also demonstrated the presence of $17 \beta$-hydroxysteroid dehydrogenase in the gonads of normal boars and intersex pigs suggesting that the biosynthetic steps leading to the formation of oestrogens may be similar in normal boars and intersexes. Furthermore, it has been shown that a large part of the steroid metabolite leaving the testes of normal adult boars consists of sulphated oestrogens (Raeside, 1966). Although the exact nature of the steroid elaborated by the foetal testes is not known at present, it would appear that the presence of sulphated oestrogens in the testicular excretion in pigs may be causally related to the escape from sterilization of the developing female gonad.

This investigation was supported in part by a grant in aid of research from the Medical Research Council of Canada. The technical assistance of Mrs D. G. Friedman is gratefully acknowledged.

\section{REFERENCES}

Basrur, P. K. \& Coubrough, R. I. (1964) Anatomical and cytological sex of a Saanen goat. Cytogenetics, 3, 414.

Basrur, P. K. \& Kanagawa, H. (1970) Anatomic and cytogenetic studies on intersex goats. Ann. Génét. Sél. anim. 1, 349.

Basrur, P. K., Kanagawa, H. \& Gilman, J. P. W. (1969) An equine intersex with unilateral gonadal agenesis. Can. F. comp. Med. 33, 297.

Basrur, P. K., Kosaka, S. \& Kanagawa, H. (1970) Blood cell chimerism and freemartinism in heterosexual quadruplets. 7. Hered. 61, 15.

Breeuwsma, A. J. (1970) Studies on intersexuality in pigs. Ph.D. thesis, Research Institute for Animal Husbandry "Schoonoord". Ziest, The Netherlands.

Bruere, A. N., Fielden, E. D. \& Hutchings, H. (1968) XX/XY mosaicism in lymphocyte cultures from a pig with freemartin characteristics. N.Z. vet. F. 16, 31 .

Cox, J. E. (1968) A case of a fertile intersex pig. F. Reprod. Fert. 16, 321.

FolGER, A. F. (1932) A case of hermaphroditism with pregnancy in a pig. Acta path. microbiol. scand. Suppl. 8-11, 143.

Goodrellow, S. A., Strong, S. J. \& Stewart, J. S. S. (1965) Bovine freemartins and true hermaphroditism. Lancet, i, 1040.

Hammerton, J. L., Dixon, J. M., Pollard, L. E., Grieves, S. A. \& Short, R. V. (1969) Genetic intersexuality in goats. 7. Reprod. Fert. Suppl. 7, 25.

Hulland, T. J. (1964) Pregnancy in a hermaphrodite sow. Can. vet. F. 5, 39.

MaFEe, A. F., KNIGHT, M. \& BANNER, M. W. (1966) An intersex pig with XX/XY leukocyte mosaicism. Can. F. Genet. Cytol. 8, 502.

McFeely, R. A. (1967) Chromosome abnormalities in early embryos of the pig. F. Reprod. Fert. 13, 579.

Ohno, S., Trujillo, J. M., Stenius, G., Christian, L. C. \& Teplitz, R. L. (1962) Possible germ cell chimeras among newborn dizygotic twin calves. Cytogenetics, $1,258$.

Raeside, J. I. (1966) Secretion of steroid sulfates by the testes of the boars. Proc. Can. Fed. Biol. Soc. 25, 1966.

TePlitz, R. L., Moon, Y. S. \& BasRur, P. K. (1967) Further studies of chimerism in heterosexual cattle twins. Chromosoma, 22, 202.

Vogt, D. W. (1968) Sex chromosome mosaicism in a swine intersex. F. Hered. 59, 166. 